\author{
Changing Societies \& Personalities, 2017 \\ Vol. 1, No. 1 \\ http://dx.doi.org/10.15826/csp.2017.1.1.004
}

Article

\title{
Religious Education: Meeting and Countering Changes, - Changing and Standing Still ${ }^{*}$
}

Tim Jensen

University of Southern Denmark

\begin{abstract}
I shall venture to map and discuss how (certain) states in the Western part of Europe have responded to the challenges of increased religious pluralism and individualism, in particular, new Muslim presence and new Islamophobia. The main focus will be on the changes as regards the $\mathrm{RE}$ offered and supported by the state in public school. The conclusion reached by my analysis is that there have been some changes to RE as a reflection of and response to the changes taking place in society and in the world at large as regards religion, but some of the responses and changes to RE seem to be changes and responses meant to counter, if not stop, the changes that have to do with religion, the role of religion in society at large and the meaning (or not) of religion for individuals. One can witness a strange mixture of responses: on the one hand, an opening up of the contents and approaches of the RE to the increasingly multi-religious society, and, on the other hand, an effort to use RE to protect and boost the national religio-cultural situation of the past, e.g. by way of promoting the traditional majority religion of the state, and by, inter alia, insisting on its key role for the (unchanging) national identity. The core aims, thus, of the $R E$ often remain unchanged even if certain terms and aims do reflect that times have changed.
\end{abstract}

\footnotetext{
* This article is of course based upon much of what I have been reflecting upon and written about in relation with the subject matter for decades. Parts of the data, analysis and reflections thus also have appeared in earlier articles, inter alia in "ASR and RE", an article written in honor of Prof. Brian Bocking and published in the Journal of the Irish Society for the Academic Study of Religions 3 (2016), 59-83. Thanks to the editors for their permission to recycle parts of that article here.
} 


\section{KEYWORDS}

Religious pluralism; Western Europe; religious education; national identity; majority religion; confessional education.

\section{Introduction}

French sociologist of religion, J.-P. Willaime, former Director of the (French) Institute européen en sciences des religions (IESR), an institute set up by the French government in order to stimulate and strengthen teaching about religion as a dimension within other school subjects (e.g. by way of producing qualified textbooks as well as offering in-service teacher-training) in an overview of RE in Europe wrote (Willaime 2007, $57 \mathrm{f}$ ) that all kinds of religious education (RE) in Europe were facing the same kind of challenges caused by the same kind of change, namely, an increased religious pluralism and individualism.

Though I would add and stress that 'religious pluralism and individualism' include an increase in many countries of so-called nones as well as of outright atheists, and though, as regards challenges, I find it unavoidable to emphasize the importance - for all kinds of thinking about RE, religion and religious pluralism - of the new Muslim presence and (not least) the various kinds of old and new Islamophobia. I cannot but agree with Willaime. ${ }^{1}$ Also today, in 2016.

In what follows, I shall venture to map and discuss how and to what a degree (certain) states in the Western part of Europe have actually responded to the mentioned challenges and changes as regards the RE offered and supported by the state in public school. Though many countries have highly developed private- school system and though allowing supporting, funding and establishing (and controlling, inspecting and sometimes closing) e.g. Muslim private schools, and though developments within the private religious schools system can

\footnotetext{
${ }^{1}$ For discussions on definitions of 'Islamophobia' as well as references, see inter alia Otterbeck, J. and P. Bevelander 2006. I use the term to refer to hostile and fearful (at times also dicriminatory and neo-racist) attitudes, actions, and discourses on Islam and Muslims based primarily on prejudice, generalisations and stereotypes. For an Islamophobia in Denmark, see Jensen 2012.
} 
also be seen as a response (also a state response) to change and the religious pluralisation, I have not included this in the following.

Amongst the conclusions reached by my description and analysis mention may be made of a few overall ones: there have been some changes to $\mathrm{RE}$ as a reflection of and response to the changes taking place in society and in the world at large as regards religion, but, as it will be clear, some of the responses and changes to RE seem to be changes and responses meant to counter, if not stop, the changes that have to do with religion, the role of religion in society at large and the meaning (or not) of religion for individuals.

Likewise, one can witness a strange mixture of responses: on the one hand, an opening up, in various ways, of the contents and approaches of the RE in question to the increasingly multi-religious society, and, on the other hand, and, at the same time, an effort to use RE to protect and boost the national religio-cultural situation of the past, e.g. by way of promoting the traditional majority religion of the state, and by, inter alia, insisting on its key role for the (unchanging) national identity. The core aims, thus, of the $R E$ in question, quite often remain unchanged even if certain terms and aims do reflect that times have changed. Even as regards the introduction of an alternative subject to the traditional confessional RE offered, it often turns out that the alternative is no 'real' alternative but rather a substitute for a (confessional) RE, a confessional RE traditionally thought to be a provider of not least the moral supposed to be the foundation of the good society.

\section{Mapping out RE - and Changes to RE Reflecting Societal and Religious Changes}

Mapping out and ever so briefly discussing responses to changes necessitates mapping out the various kinds and modalities of RE. "Religious education" (RE) is a (highly) generic term that can (and actually does) include all kinds and often very different kinds of teaching religion. RE, and here I only look at religious education in public schools, comes in many shapes, and each shape, besides, comes in many shades. 
Maps and models are supposed to be less complex than the empirical complexities they try to map, overview, reduce and handle. But RE, in its various shapes and shades, is mapped and classified in so many ways - and the classifications are based on such a variety of criteria - that readers who are not well read in the relevant literature are likely to get lost. Here follows my classification and overview, - and I can only hope that the reader does not get lost and refer her to some of the many other overviews. ${ }^{2}$

\section{Confessional RE}

$\mathrm{RE}$ in public state-run (otherwise) secular education and public schools, be it elementary or upper-secondary school, may be a timetabled Confessional RE, state supported (in various ways) and (as in Germany) taught by teachers educated, not in the normal state institutions for teacher training, but in institutions run by the 'confession' (majority or minority religion, denomination etc.) in question.

Though confessional RE comes in various shapes and shades (Finland for example having its own special kind, maybe more correctly termed 'separative' rather than 'confessional' RE), ${ }^{3}$ it normally takes as its starting point the religious teachings of the religion/confession/ denomination in question, and it has, one way or the other, the aim of making those religious teachings religiously and morally relevant to the pupils. Pupils, who are normally, though not exclusively, children of parents who 'adhere' or 'belong' to the religion/confession in question.

Confessional RE is always a kind of learning religion or learning from religion, especially or exclusively learning from 'one's own' religion, and it aims at making the pupils religiously competent, as it is sometimes expressed. It is teaching into the religion or denomination in question. 'Religious instruction', 'Religious upbringing' or 'religious

\footnotetext{
${ }^{2}$ Many of the books and articles on RE listed in the references to this article have some kind of account of the various terms and kinds of RE. However, from my studyof-religions perspective specific mention may be made of: Alberts 2006, 2007, 2008, and 2009; Jensen 2005; Willaime 2007. Byrne 2014 also has useful overviews and discussions. For more recent overviews and discussions from other perspectives that a study-of-religions perspective, cf. e.g. Jackson 2014, and Schreiner 2015.

${ }_{3}$ For inland, see Sakaranaho 2013.
} 
nurture' are terms that may therefore at times be applied too, despite the fact that these terms may also be used for religious education taking place within the religious institution itself (or in the home) rather than in the public school.

One may also speak more broadly about 'religious' RE as well as of 'interreligious' RE, - over against 'non-religious' or 'secular' $\mathrm{RE}$, - a terminology that may be preferred in order to e.g. avoid that 'confessional RE' is used only when the kind of RE in question is identical to a kind of catechism and exclusively based upon and aimed at a formulated 'confession' or creed.

As a consequence of an increase in certain kinds of religious pluralization and/or pluralism(s), e.g. an increased presence, in a nation or region, of parents and pupils with various kinds of religious or denominational backgrounds, systems of confessional RE, e.g. in various 'Länder' in Germany, tend to become systems of multiconfessional RE, with each religion or denomination (Islamic, Jewish, Apostolic etc) establishing and running, with the support of the state, its own confessional RE in the public school. ${ }^{4}$

Apart from the development into a system of multi-confessionalism in places with confessional RE mention must, of course, also be made of the necessity to have an opt-out possibility and to offer an alternative subject, non-confessional, to confessional RE. The human rights 'regime' is evidently in place most places and it has necessitated changes also as regards $R E$ in school, and the increase in religious pluralisation implies an increase in non-religion, also amongst parents and pupils formally belonging to one religion or denomination. The opt-out option sometimes also exists even if the RE in question is, in accordance with the laws of the land, in principle non-confessional. This is, for example, the case in elementary school in Denmark as well as in Norway, and in both countries this is to make sure that the state is not taken to court by some stakeholders (e.g. minority religions or denominations, humanist associations, and parents) who think (correctly or not) that that the $\mathrm{RE}$ in question does not qualify as 'objective, critical, and pluralistic',

\footnotetext{
${ }^{4}$ See e.g. with regard to Bavaria in Germany Jensen \& Kjeldsen 2014d.
} 
the criteria staked out for a compulsory RE by the European Court of Human Rights (ECHR) as well with as by US Supreme Court. ${ }^{5}$

Likewise, most confessional RE nowadays includes some teaching of and about 'other' religions. ${ }^{6} \mathrm{~A}$ critical look at the inclusion of other religions in the curriculum in confessional $\mathrm{RE}$, however, reveals that quite often this teaching does not comply with basic study-of-religions standards for a series of reasons:

Though the teachers teaching about other religions within the framework of confessional RE may have had some kind of education qualifying them for this, most confessional RE-teachers have not been educated at something comparable to study-of-religions departments and thus have not acquired the cross-cultural, critical, comparative and historical knowledge and competences, knowledge and competences necessary also in order to minimize the risk that teaching about the other religion(s) takes place on the basis of and from the viewpoint of the teacher's own religion and insider-notion of religion.

Linked to the inclusion of teaching about (other) religions in confessional RE is a widespread ecumenical aim, or, as it is more often called, interreligious or interfaith inspiration and aspiration. Teaching of one's own religion and the religion(s) of others (also sometimes the others sitting in the classroom) aims at providing the pupils with not just religious but interreligious competence. The so-called Hamburg way of doing things, with protestant theologian Wolfram Weisse as a

\footnotetext{
5 See Jensen 2005 for a discussion with reference to human rights norms, and Andreassen 2013 on the problems for Norwegian RE to meet the human rights standards. The Norwegian case, in an exemplary way, indicates how hard it is for an, in principle, non-confessional RE to comply with not just human rights but also with study-of-religions standards. It may be added that the opt-out possibility is only partial in Norway: the pupils can only be exempted from those parts of the RE teaching (and those parts, actually, of all teaching in school, which they (or their parents) deem to be religious or religious-like practice. In Denmark, they can be totally exempted, but only from RE. In both countries there is no alternative offered, but in Denmark the parents are supposed to educate their child in their own religion. There is, in both countries, no opt-out possibility in upper-secondary school, no doubt because the RE in question is more (or totally) study-of-religions based.

${ }^{6}$ Examples may be found in the so-called baseline studies on RE in Spain, Italy and Germany produced by Jensen \& Kjeldsen $2014 \mathrm{bcd}$.
} 
leading figure, is a good example of this combination of confessional and interreligious (or: 'inter-faith' or 'inter-confessional') RE.'

\section{Interreligious (or Intercultural or Multicultural) RE}

Though there are instances of confessional RE that turns into some kind of inter-confessional or interreligious RE, one might also argue that this kind of RE or more 'full-blown' kinds explicitly interreligious $\mathrm{RE}$ must be mapped as a special kind of response to the changes in or towards new kinds of religious pluralism. In what follows I shall therefore take a brief look at this class of RE.

'Intercultural education' (ICE), 'multicultural education' (MCE), 'interreligious education' (IRE) (not to be mistaken for IRE = 'Islamic religious education'), 'interfaith education', and 'intercultural religious education' are all terms flourishing on the 'market'. And, like RE, they are all far from self-explanatory.

What they are or what they intend to be can only be determined from case to case following an elucidation and analysis of the relevant source material. They may also be taught in schools in various ways: as im- or explicit dimensions of other specific time tabled school subjects (e.g. history or a timetabled RE), as im- or explicit dimensions and practices of the school and education system as a whole, or as specific time tabled school subjects in their own right so to say.

Both intercultural and multicultural education often imply a kind of education, teaching and learning that is aimed at supporting and strengthening identities, (equal) rights and social/cultural inclusion of various cultural and religious groups and the individuals pertaining to those groups. A support and an inclusion seen as essential to the well-being of the groups and individuals in question and to the larger multicultural society and world.

It is therefore quite often an im- or explicit part also of what is called 'citizenship education', and it is thus also often linked to education

\footnotetext{
7 For one of many brief introductions to the "Hamburger Weg", see Doedens \& Weisse 2007. For a brief critical overview with references to further study-of-religions based critical analysis, inter alia by Christoph Bochinger, of this kind of confessionalinterreligious RE, see Frank 2010, 27-29. Linked to this kind of confessional RE in Hamburg is the so-called Akademie der Weltreligionen at the University of Hamburg. See http://www.awr.uni-hamburg.de (last accessed February 20, 2016).
} 
aimed at promoting democracy and human rights. Only a case -bycase study, however, may reveal to what a degree the stipulated or factual education or teaching does not only recognize, respect and tolerate diversity, especially cultural or religious diversity, but does also 'celebrate' it and move beyond recognition to dialogical (inter-)action with a possibility of promoting and generating shared cross-cultural or cross-religious notions and practices.

In most cases, it is learning about others in the presence of each other, and in some cases it is learning from the others in the presence of each other. The last mentioned possibility often is implied in the term 'dialogue' as well as in what is sometimes called 'interreligious education'. Since religion is often (considered) an important element in culture and identity (construction), intercultural as well as multicultural education is not rarely paying attention to religion, and it thus also often linked to interreligious or interfaith education.

\section{Transnational (Recommendations) for RE}

Recommendations from the much advertised and influential REDCo (Religion in Education. A Contribution to Dialogue or a Factor of Conflict in Transforming Societies of European Countries $)^{8}$ project, as well as the aims and policy of the equally influential ENRECA network (The European Network for Religious Education through Contextual Approaches), ${ }^{9}$ in various ways show clear signs of the characteristics

\footnotetext{
${ }^{8}$ The project, financed for three years, 2006-2009, by the research department of the European Commission, included projects linked to eight countries. The project has resulted in several books published by Waxman, Münster, and in even more articles. The US journal Religion \& Education devoted a special issue (Vol. 37, Number 3, 2010) to the project. With an introduction by W. Weisse, ibid. 187-202, and "responses" from invited scholars, including my own critical one (Jensen 2010).

9 The policy statement of ENRECA, written by Siebren Miedema, Peter Schreiner, Geir Skeie, and Robert Jackson may be downloaded from several URLs. One is the Comenius platform at http://www.comenius.de/pdfs/themen/Europa-enreca.pdf (last accessed Februay 20,2016). The Comenius-Institut, by the way, represented by its former director as well as by its present director (Peter Schreiner) has been prominent and very influential in the field of European RE for decennia, an indication of a characteristic mixture of scholarly as well as religious interests and affiliations to be found on the European RE scene. Schreiner, has, it must be emphasized, time and again produced solid and helpful research based overviews of RE in Europe.
} 
of interreligious education: religions are seen as spiritual and moral resources for the pupils and for society, teaching about is combined with teaching from the insider's perspectives, learning about is also learning from, and RE is seen as having much more to accomplish than providing knowledge and analytical skills.

If not there to save the world, it (RE) is there to, at the least, play a key role in paving the way for tolerance, social cohesion, peaceful coexistence, human rights, and freedom of religion, and it is supposed to function as an anti-dote to what is seen as a growing fragmentation, lack of spiritual and moral orientation, and gross materialism. In brief: important cultural and societal changes, conceived of states and certain stakeholders to influence societies and individual in negative ways.

The RE in question, recommended or 'for real', is thus aiming at contributing to the formation of what has been called 'the whole child', as well as of what is thought to be a 'wholesome' society. With reference to the famous UK based 'gift to the child'-project and-pedagogy (cf. inter alia Alberts 2007, 120-130 for an overview and references) one can say that this kind of interreligious RE sees itself as a gift to the child as well to society at large, the cohesion of which it contributes to while functioning also to develop interpersonal (moral) values and interreligious competences.

Several other of the transnational recommendations and projects, projects which have received at least some publicity beyond the ranks of RE-linked scholars and policy makers, at a first glance seem to recommend a study-of-religions approach, teaching about religion. Yet, quite a few, e.g. the Council of Europe's project(s) on intercultural

\footnotetext{
Nevertheless, it must also be noticed that (cf. the Comenius-Institut website) this key RE-player is at the same time director of the Comenius-Institut (Muenster, Germany), a Protestant Centre for Research and Development in Education. Consequently, it must be noted that a key player like Schreiner who has also been central in the EFTRE, the European Forum for RE-teachers, and who is moderator of the Coordinating Group for Religious Education in Europe (CoGREE), at the same time is also president of the Inter-European Commission on Church and School (ICCS), a non-governmental organization with participatory status at the Council of Europe and an associated member organization of the Conference of European Churches.
} 
education, actually stress that learning about is not enough. ${ }^{10}$ This is true also for the recent 2014 publication edited by Robert Jackson (Jackson 2014), beyond a doubt the most influential contemporary RE-scholar and policy maker. The publication (Chapter 2) inter alia stresses that religion cannot be reduced to a cultural fact, that understanding must include the understanding of the insider's perspective, and that it takes imagination and empathy to understand religion. This, as well as the explicit recommendation of e.g. a dialogical approach, is not in line with a study-of-religions approach, even if the publication at various places speaks of the kind of RE recommended for schools in terms of 'study of religions' ('studying religions') in school.

The same can be said about another response, The Toledo Guiding Principles issued by the OSCE, to the changes and 'challenges', especially religion-related changes and challenges conceived of as a threat to the security of the OSCE member states. The Toledo Guiding Principles is a thorough recommendation to member states to implement a non-confessional kind of RE in public schools, and time and again, the The Toledo Guiding Principles refers to the study of religions as the academic basis for $\mathrm{RE}$ (and the educational background of RE-teachers), and time and again it stresses that it is teaching about that is recommended. Yet, at the same time it displays, as pointed out by the present writer (Jensen 2008, 132-133), several clear examples of an approach to religion and RE not specifically characteristic of an academic study of religion.

Nevertheless, some responses, e.g. the Toledo Guiding Principles, to changes and challenges, do, I think, also constitute a step in the direction of a study-of-religions non-confessional RE, another response to the challenges of course, and a response looked at closer ahead. It does so even if it does so in a 'flawed' way. The same, of course, goes for the many conferences and discussions, not least in French-speaking and Catholic countries, also those that have looked for inspiration in Canadian Quebec and its recent introduction of the so-called Ethics and Religious Culture (ERC) program.

\footnotetext{
${ }^{10}$ See the critical overview with references in Jensen \& Kjeldsen 2014 a.
} 
Though I cannot go into details, the ERC, however, just like e.g. the abovementioned Toledo Guiding Principles at a closer look is evidently not fully emancipated from a confessional approach. It is not a regular study-of-religions based RE, neither as regards its explicit intercultural and interreligious dialogue aims nor as regards its contents. Scholars of religion and RE-specialists Bengt-Ove Andreassen (Norway) and Satoko Fujiwara (Japan) in their critical contributions to a special issue of Religion Education (Andreassen 2011; Fujiwara 2011) both agree that 'deconfessionalisation' has not been fully completed with the ERC.

\section{Alternatives to Confessional RE: Ethics, Ethics and Values, \\ Philosophy, et al}

As indicated above: religious pluralism(s), including non-religion and atheism, individualism, secularisation and the human rights regime all have made it necessary for states having and supporting a confessional RE-system to include into the system an opt-out possibility, a possibility at times limited or supplemented by the offering of a voluntary or compulsory alternative to confessional RE. Though this might be - and in Spain at a time has been - a non-confessional study-of-religions based RE - the general picture shows that states in general prefer to offer an alternative which, at least in its name, does not signal any teaching about religion. The many alternative subjects offered to pupils opting-out of a confessional RE have many names (Ethics, Philosophy or a combination), and a few actually do offer some teaching about religion.

It is impossible to go into any kind of detailed overview of these responses to societal changes and religious pluralisms but a closer look at one particular case may illustrate that the alternative offered at least at times are not real alternatives but rather substitutes to confesssional RE. My case is Werte und Normen in Lower Saxony, Germany:

According to the 2009 "Kerncurriculum" (p. 7) issued by the "Kultusministerium", Werte und Normen is said to be the school subject which in particular (my emphasis) contributes to the general aims for the public school, namely to support the development of "die Persönlichkeit der Schülerinnen und Schüler auf der Grundlage des 
Christentums, des Europäischen Humanismus und der Ideen der liberalen, demokratischen und sozialen Freiheitsbewegungen"(§2).

Though the wording of $\S 2$ tends to indicate that the values and norms linked to or implied in Christianity, Humanism, and the mentioned "Freiheitsbewegungen", are, if not eternal, then at least sufficiently stabile to constitute a foundation ('Grundlage'), the text, nevertheless, at the same time addresses the dynamic changes and plurality of values and norms (supposedly also those implied in the abovementioned 'Grundlage'), as well as what is considered a result thereof, namely 'Orientierungsprobleme' - for the modern human being and not least for the pupils.

Kant's (normative) question "Was soll Ich tun?"is considered key to the identity of the school subject, something that becomes evident also from the listing (p. 11) of the contents related areas of competence ('inhaltsbezogene Kompetenzbereiche'): 'Fragen nach dem Ich', 'Fragen nach der Zukunft', 'Fragen nach Moral und Ethik', 'Fragen nach der Wirklichkeit', and 'Fragen nach Religionen und Weltanschaungen'. Being able to reflect on one's own as well as other's positions, values and norms, and thus by way of such (self-)reflection developing the 'Persönlichkeit' of the pupils, includes a stipulated capability to be able to enter into a dialogue and discuss with each other in the classroom and in society at large, - on a basis of nuanced knowledge and in a reasoned and qualified manner. The developed 'Persönlichkeit', thus, is not an isolated individual moral being but also a competent social being, a 'mündig' citizen.

As regards religion(s): the core curriculum expresses a notion of religion as essentially 'about' so-called existential questions, i.e. questions postulated to be posed by all human beings, questions about life and death, meaning, identity, etc. Teaching about and learning about religion(s) thus also becomes learning from religion(s).

On this background, it is difficult not to see Werte und Normen as a school subject in which the teaching is not just about morals (from, say, a philosophical or sociological point of view). Aims and contents reveal that this subject also aims at providing morals, or as said above, Werte und Normen seems to be more of a substitute for than a real alternative 
to confessional RE. It is the school subject particularly tailored to taking care of that moral and societal upbringing that used to be the business of confessional RE. Werte und Normen, thus, may very well be compared to and seen as an example of (Frank) 'life world-related RE', maybe also as a (Jensen \& Kjeldsen) kind of 'small-c confessional $R E$ '. Kinds of RE that may be found within formally non-confessional $\mathrm{RE},-$ to which we turn in the next section.

Before doing so, however, it must be mentioned, that, Werte und Normen, just like e.g. Toledo Guiding Principles, arguably may also be said to, after all, constitute a step in the direction of nonconfessional RE, and there is clear evidence of efforts to strike a balance between the normative and informative when the text explicitly mentions that teaching Werte und Normen, in contrast to confessional $\mathrm{RE}$ (Religionsunterricht), must be neutral in regard to religion and worldviews. Normative ('binding') 'answers' to the fact of a plurality of truths and the fundamental moral questions can be given, it is furthermore stated, only with reference to the [German] Constitution and the educational aims in general, not with reference to religious or 'weltanschaulicher' premises (p. 8, note 1). Moreover, the academic basis of the subject is clearly demarcated from a theological and confessional religious base, since the three "Bezugswissenschaften" are (applied) Philosophy, The Study of Religions ("Religionswssenschaft"), and (various) social sciences (p. 9). Werte und Normen - teachers, moreover, are educated accordingly.

\section{Citizenship Education}

Mention must also be made, and more explicitly than done above, of another 'response' to the common challenges mentioned, namely the introduction or development of so-called 'citizenship education.' In recent citizenship education in France, according to sociologist of religion, Valentine Zuber (Zuber 2016), the "moral code taught is [...] more of a tool that provides an upbringing than one for education." While French citizenship education may have a special tenor to it due to the French notion of laïcite, citizenship, and nation, including a claim that the 'morale laïque' is a universal moral code, a tenor also 
reflecting shades of a notion of the sacredness of the Republic 'as such', other kinds of citizenship education more or less explicitly refer to the importance of the Christian 'roots' and tradition for the present (postulated) democratic and civic values. Citizenship education (and RE) for that reason enters into several kinds of 'alliances' or combinations, some of which include the teaching about a growing number of other religions than Christianity in order to pave the way for tolerance, societal harmony, and sometimes, of course, interreligious or intercultural understanding and competences. A combination of, on the one hand, a neo-nationalist promotion and knowledge of 'our' values and the good citizen as humanist and Christian, and, on the other, of a more cosmopolitan citizen and multi-cultural or religious plural world and society can also be found. An example maybe of what has been termed 'glocalization'.

The neo-nationalist, pro-Christian aspect and agenda most certainly played a significant role when citizenship education in 2007 was linked in a most conspicuous manner to an existing compulsory RE subject (to be read by all future teachers in the Danish elementary school, not just those teaching $\mathrm{RE}$ ). The then new compulsory subject was called by the somewhat hybrid name KLM (Kristendomskundskab, Livsoplysning, Medborgerskab $=$ Knowledge of Christianity/Enlightenment of Life/ Citizenship). The equally hybrid subject, to be taught not by social scientists but by teachers a large part of whom were educated as theologians, consisted of three knowledge areas: Religion and Culture, the History of Philosophy, and Democracy and Citizenship. Besides Christianity, Islam and Judaism as minority religions in Europe were obligatory.

Two paragraphs of the 2007 curriculum deserve particular attention (and they were also publicly discussed). One of them deals with the general objectives, saying that the students should gain competences in order to "[...] relate to the impact of Christianity and other world-views ('livsanskuelser') on the foundational values in a European and Danish cultural context" (Undervisningsministeriet 2007, 2.2). The other one was listed as contents under "Religion and Culture". It read: "The impact ('betydning') of Evangelical-Lutheran Christianity on democracy, the 
welfare state and the school in Denmark" (Undervisningsministeriet 2007,2.3.1).

A report made after the first year of implementation found that many students seemed to have acquired a highly simplified 'understanding' of democracy, the welfare state and human rights as a direct heritage of Christianity - something they, moreover, had learnt to see as being in opposition to Islam not least. The students, according to the report, also expressed a "secularized culture-Christian" perspective, with no critical look at all at the historical impact of Christianity and on the church as a powerful and dominating institution (Brandt \& Böwadt 2009).

A 2012 research project by Karna Kjeldsen, analyzing inter alia local syllabi, reached a less critical conclusion as regarded the actual implementation of the national curriculum. However, it also documented that a majority of classes had primarily read literature with a positive version of Evangelical-Lutheran Christianity and its impact on Danish culture, the welfare state and democratic values (Kjeldsen 2012). Furthermore, it must be added that in a recent (2013) revised version of the national curriculum for KLM the neo-nationalist (cultural-Christian discourse has been played-down, and the paragraphs on the direct impact of Christianity (Evangelical-Lutheran especially) on European and Danish democracy and values have been totally deleted (Ministeriet for Forskning, Innovation og Videregående Uddannelse 2013).

\section{Non-Confessional RE}

Another kind of reaction to the development towards more (or: other kinds of) religious plurality as well as to developments like secularization and individualization, are of course efforts, mostly in vain, e.g. in Spain and Italy (cf. Jensen \& Kjeldsen 2015 with references), as well as in Germany and Belgium (cf. Alberts 2007 and Franken 2016) towards the establishment of (some kind of) non-religious or non-confessional $R E$. And, in places where (at least in principle) non-religious, nonconfessional RE has been in place for years or even decades, (then) coming into being of such non-religious RE may, of course, be seen as a response to changes and challenges mentioned: secularization, (another kind of) religious pluralism, individualism etc. 
Non-confessional RE, however, may be a lot of 'things'. It is, in principle at least, a kind of RE that, legally as well in practice, and contrary to confessional RE, is not, legally and formally, based upon or intimately linked to the (explicit) teachings of one specific religion. And non-confessional RE teachers are, normally, not educated by religious institutions but at normal teacher-training institutions, including, in some countries, universities and university departments e.g. departments for the scientific, historical and comparative study of religions. In non-confessional RE, in principle, the religions taught about are to be approached on equal terms; theories and methods applied are, in principle, the same no matter what religion is taught. It is teaching and learning about religion(s), and it is not rarely explicitly claimed that it is so in ways in line with the academic study-of-religions perspectives. It could be added that it is often thought to be, in principle, this kind of RE that can comply with the above mentioned criteria put forward by the European Court of Human Rights (ECHR) as well with as by US Supreme Court for a compulsory RE, an RE that does not violate the rights of the parents as regards (religious) education, because it is 'objective, critical, and pluralistic', and it is not infrequently said to be this kind of RE that may be found in England and Scotland, as well as in the Scandinavian countries.

Before a more critical look at certain kinds of this kind of RE, it may be useful to introduce a few more analytical categories developed by study-of-religions scholars:

The first useful typology has been developed by Katharina Frank on the basis of research on $R E$ in Switzerland. Based on various empirical (re-)sources, classroom observation included, Frank distinguishes between (a) 'religiöse' and (b) 'kulturkundliche' framings of religion in $\mathrm{RE}$. The two kind of framings are then subdivided into, on the one hand, (a) narrative $R E$, dogma-related $R E$, and life world-related $R E$, and, on the other hand (b) historical RE, sociological RE, and systematiccomparative RE. ${ }^{11}$ With reference to Frank's analysis and classification of 'life-world-related RE' as a kind of religious RE, a closer look at nonconfessional RE from the point of view of a study-of-religions scholar

\footnotetext{
${ }^{11}$ See, inter alia, Frank 2010, and 2015; Frank \& Bochinger 2008.
} 
clearly shows that many a so-called non-confessional kind of RE actually is 'life-world-related' and thus religious, or religiously framed, RE.

Another classification and category, 'developed' by this author together with Karna Kjeldsen, is based upon the one proposed by Donald Wiebe (Wiebe 1984) for theology and theology-like (or religious) studies of religion. With reference to Wiebe, we proposed to operate with, respectively, 'Capital-C Confessional RE' and 'small-C confessional RE'.

While the latter is formally and maybe also in realiter dissociated from a specific religious confession (or a specific religious tradition), it continues to be based on a religious understanding of religion, and to have the ex- or implicit aim of promoting (some kind of) religion, religiosity, or religion-based values in general. Wiebe wrote:

All uncritical thinking about Gods or the gods that rests on revelation and authority or on the "presumption of theism", and that therefore refuses to countenance the possible non-existence of God or the gods, is "confessional theology". Such theology constitutes a species of what I prefer to think of as "religious thought" which operates entirely within the framework of general religious assumptions, or within a particular religious tradition, and is, therefore, incompatible with what will be referred to below as the basic minimum presuppositions for the academic study of religion (Wiebe1984, 405).

Analyses of many kinds of so-called non-confessional and nonreligious RE reveal many traces of such 'religious thinking', whether it operates within the framework of general religious assumptions or a particular religious tradition, and I consider such cases to be a kind of 'small-c confessional' RE, sharing many characteristics with Frank's 'life world related RE'.

Turning more directly to established educational systems with a declared non-confessional RE, a look at the situation in e.g. England taken by Wanda Alberts in her 2006 dissertation (Alberts 2007, 86 $\mathrm{ff}$, and (a brief exposé) Alberts 2010, 277f) shows with crystal clarity that a lot of RE in England cannot even with the best will be seen as in line with an study-of-religions approach. There is a lot of RE that may described as much more in line with e.g. the already mentioned 
'a gift for the child' approach, ${ }^{12}$ and thus not just multi-faith but rather interfaith RE.

A more recent report (by the UK Religious Education Council) of the purpose, aims and content of RE in the United Kingdom, summarized by the editor to the British Journal of Religious Education, speaks its own clear and honest language as regards the messy situation:

Is religious education an academic study of the beliefs and values of others, or more a form of personal development in which pupils work out their own important beliefs, values and identity? [...] Is it a non-confessional activity or is there a place for faith development? What is the place of philosophy and ethics? Can religious education contribute to social and political goals such as community cohesion, global citizenship or saving the planet, or is this ridiculously overambitious and distracting from the core purpose? (Editorial, British Journal of Religious Education, vol. 35, no 3, 2013)

Moving from England and the UK to Scandinavia, not rarely considered a stronghold of non-confessional RE, with Sweden and Norway introducing it as early as in 1969, and Denmark, (elementary school) 1975, the situation, especially as regards RE in elementary school, is also somewhat ambiguous.

As scholars of religion, Jenny Berglund (2013), Bengt-Ove Andreassen (2013) and Tim Jensen \& Karna Kjeldsen (2013), have demonstrated, RE, not least in elementary school in each of these three countries, may be said, as indicated in the title of the 2013 article by Berglund, to be 'marinated in' Lutheran-Protestant Christianity. In each of the three countries RE is linked to a (neo-) nationalist culturalist agenda of inculcating (a notion of) so-called Christian values and Christian (cultural) heritage in the pupils and future citizens via RE.

In Denmark, furthermore, such a (neo-)nationalist agenda as regards $\mathrm{RE}$ and the promotion of Christianity as foundational for the past and present Danish society and culture, is coupled with a pro-religious agenda promoting some postulated 'religious dimension' (clearly some sort of Tillich-inspired theological notion) said to constitute a universal

12 For the "gift to the child" approach and project with references, see Alberts 2007, $120-130$. 
human and ontological fact that, strangely enough, is totally in line with Danish theological-existentialist life-philosophy.

Despite some recent attention to providing more solid knowledge, this RE primarily aims at having children realize that the postulated religious dimension is important, to them and everybody, since every religion at its basis has this 'religious dimension' and a quest for 'meaning'. At a closer look, the 'religious dimension' as well as the key thematic and pedagogical unit, the philosophy-of-life, is, as first formulated by Pia Rose Böwadt, nothing but 'Christianity in new clothes'. The teaching supposed to be teaching about is in fact 'preaching the gospel of this 'religious dimension' and of Danish culture as Christian culture (cf. Jensen \& Kjeldsen 2013, 195 ff).

Unfortunately, this crypto-confessional or 'small-c confessional RE' can be seen elsewhere too, for instance in Switzerland, as shown by e.g. Andrea Rota (Rota 2013). Also on the basis of research on $\mathrm{RE}$ in Switzerland, religion scholar Katharina Frank (at times with Christoph Bochinger) has, as mentioned above, developed another highly useful classification of RE. The discussion of the category 'life world related RE' and the demonstration, with reference to the analysis of the relevant empirical material, why this pertains to the larger class of religious RE, is particularly useful: In 'life world-related RE' the aim is to link the objects of the teaching, i.e., religious figures, narratives, dogmas, rituals etc. to the life world and experience of the pupils and thus to make the pupils familiar with what is considered universal human themes and experiences: the aim is to develop the personality, spirituality, and 'humanity' of the pupils.

When pupils in many a RE classroom are imagined to develop respect and understanding for other religions and for those (other) pupils and persons who 'adhere' to these religions, the 'otherness' of the other religion(s) may be stressed. ${ }^{13}$ It may, however, also be

\footnotetext{
13 In Denmark, for instance, by way of seeing 'our' (way of having) religion as compatible with a secular democratic state, with secularization, human rights, and gender equality, at the same time as it is seen as a challenge to the other religions (Islam not least, of course). Another 'strategy' is to describe and see the religions of the others as 'religion' while our religion is primarily 'morals' and 'faith' or 'culture' or 'cultural heritage'. Furthermore, the religions of the others are religions with e.g. divine
} 
evaded or belied: the majority religion ('our' religion) and the other('s) religions all translate into universal existential themes and general human experiences. We and they can thus meet (in the RE classroom and in the hoped for better world) as humans, and 'we' can all see all religions as valuable resources for human development, mutual understanding etc. Religion, though specially the Christian one, or if religion 'in general', religion seen through some kind of Christiantheological lens, is seen as a resource for positive values, including positive moral values. A kind of RE that cannot properly be classified as study-of religions based but the kind that has taken over in many a place when confessional RE had to go.

\section{Concluding Remarks}

Many, if not most, European states seem to prefer, no matter some growing interest in some kind of teaching about more religions than the majority religion, to continue to have and to prefer to have confessional $\mathrm{RE}$, with opt-out options and a so-called alternative subject like e.g. Werte und Normen.

An increased religious pluralism, an increased focus on the role of religion in local and global politics, the role of religion in regard to socalled clash of cultures, social conflicts and terrorism, show in various ways: religions or denominations differing from the majority religion are included in the RE-teaching and a system of multi-confessionalism developed. It is still, though, 'Capital C Confessional RE', and the other religions are still seen in comparison to and from the point of view of the 'confession' or religion in power.

Added to the aims of religious and moral upbringing in line with the dominant religion in question, we now find aims linked to the needs for social cohesion in a world and society considered prone for conflict linked to a plurality of religions and cultures and to the new Muslim presence not least. RE-teaching now is therefore not just religious but interreligious 'preaching', with religions, not least the local kind of 
Christianity, as a resource which, rightly understood, of course, at the same time matches and adds to human rights and humanist values. An evident, though at times thinly veiled, aim, of course, is to use the new kind of more interreligious confessional RE to save the world from conflict, save the children from postulated evils of materialism or neo-liberalism, and to save the religion (and religions) taught from a possible future in a feared for total oblivion. Secularization understood as less religion on the societal and individual level is countered by RE. Most states with a (in principle) non-confessional RE seem to prefer to make sure that this RE not only accommodates the changes and challenges but also counter and oppose them, by way of using RE to inculcate postulated cultural-religious (Christian) values linked to the postulated cultural and (Christian) religious heritage and identity of the nation state in question.

Moreover: even when looking at fairly well-established nonconfessional kinds of RE, e.g. in the UK, and in Scandinavia, it is crystal clear that these subjects also have aims and contents that are more in line with a religious kind of $R E$, thus making it plausible to classify them as examples of 'small-c confessional RE' and/or 'life world-related RE' rather than SR-based RE.

\section{References}

Alberts, W. (2006). "European models of integrative religious education". In: Pye, M. et al (eds.), Religious Harmony: Problems, Practice and Education. Proceedings of the Regional Conference of the International Association for the History of Religions. Yogyakarta and Semarang, Indonesia, September 27th - October 3rd, 2004, Berlin/New York, Walter de Gruyter, 267-78.

Alberts, W. (2007). Integrative Religious Education in Europe. A Study-of-Religions Approach, Berlin, Walter de Gruyter.

Alberts, W. (2008). "Didactics of the Study of Religions", NVMEN, Vol. 55, Issue 2-3, 300-34.

Alberts, W. (2009). "Teaching About Religious Diversity in Schools: An Evaluation of Different European Approaches from a Study-of- 
Religions Perspective". In Berglund, J. \& L. Roos (eds.) Your Heritage and Mine: Teaching Religion in a Multi-Religious Classroom, Uppsala, Swedish Science Press, 15-24.

Alberts, W. (2010). "The Study of Religions and integrative religious education”. British Journal of Religious Education 32 (3), 275-90.

Alberts, W. (2012). "Religionswissenschaft und Religionsunterricht". In "Religionswissenschaft und Religionsunterricht". In Stausberg, M. (Hg.) Religionswissenschaft, Berlin/Boston, DeGruyter, 299-312.

Andreassen, B.-O. (2011). "On Ethics and Religious Culture in Québec: Comments and Comparative Perspectives from a Norwegian and European Context", Religion \& Education, 38:3, 266-277.

Andreassen, B.-O. (2012). Religionsdidaktik. En innføring. Oslo, Universitetsforlaget.

Andreassen, B.-O. (2013). "Religion Education in Norway: Tension or Harmony between Human Rights and Christian Cultural Heritage?", Temenos 49:2, 137-164.

Andreasssen, B.-O. (2014). "Christianity as Culture and Religions as Religions. An Analysis of the Core Curriculum as Framework for Norwegian RE", British Journal of Religious Education, 36 (3), 265-281.

Antes, P.(2010)“DasSchulfach'WerteundNormen'inNiedersachsen. Ein Beispiel für gesellschaftliche Veränderungen", In Johannsen, F. (Hrsg.) Postsäkular? Religion im Zusammenhanggesellschaftlicher Transformationsprozesse, (Reihe: Religion im kulturellen Kontext, Bd 1), Stuttgart, W. Kohlhammer, 127-136.

Berglund, J. (2013): "Swedish religion education: Objective but Marinated in Lutheran Protestantism?". Temenos 49:2, 165-184.

Brandt, A. K. \& P.R. Böwadt (2009). Medborgerskab i læreruddannelsen. Rapport til Undervisningsministeriet.

Böwadt, P. R. (2009). "The courage to be: the impact of Lebensphilosophie on Danish RE”, British Journal of Religious Education, 31 (1), 29-39. 
Byrne, C. (2014). Religion in Secular Education. What in Heaven's Name are we Teaching our Children, Leiden, Brill.

Doedens, F. \& W. Weisse (2007). "Religion unterrichten in Hamburg", Theo-Web. Zeitschrift für Religionspädagogik 6, H. 1, 50-67.

Frank, K. (2015). "Von der Grundlagenforschung zur Anwendung. Eckdaten einer empirisch gegründeten Religionsdidaktik", In Kenngott, E.-M. et al (Hgs.), Konfessionell - interreligiös - religionskundlich. Unterrichtsmodelle in der Diskussion. Stuttgart, Kohlhammer, 197-216.

Frank, K. (2010). Schulischer Religionsunterricht. Eine religionswissenschaftlich-soziologische Untersuchung, Stuttgart, Kohlhammer.

Frank, K. \& C. Bochinger (2008). "Religious Education in Switzerland as a Field of Work for the Study of Religions: Empirical Results and Theoretical Reflections", NVMEN vol. 55, Issue 2-3, 183-217.

Franken, Leni (2016). "The freedom of religion and the freedom of education in twenty-first-century Belgium: a critical approach", British Journal of Religious Education 38, 3, 2016, 308-24.

Franken, L. \& P. Loobuyck (eds.), (2011). Religious Education in a Plural, Secularised Society. A Paradigm Shift. Münster, Waxmann.

Fujiwara, S. (2011). "Has Deconfessionalisation Been Completed? Some Reflections upon Québec's Ethics and Religous Culture (ERC) Program", Religion \& Education, 38:3, 278-287.

Gaudin, P. (2014). "Enseignments des faits religieux et laïcité en France". In Willaime, J.-P. (ed.) Le défi del'enseignement des faits religieux à l'école, Paris, Riveneuve, 241-257.

Grelle, B. \& T. Jensen (2011). "Guest Editor's Preface”, Religion \& Education, 38:3, 187-187.

Jackson, R. (ed.), (2014). Signposts - Policy and practice for teaching about religions and non-religious world views in intercultural education, Strasbourg Cedex, Council of Europe Publishing. 
Jensen, T. (2005). "European and Danish Religious Education: Human Rights, the Secular State, and 'Rethinking Religious Education and Plurality'“, Journal of Religion \& Education”, 32:1, 60-78.

Jensen, T. (2008a). "RS based RE in Public Schools - A Must for a Secular State", NVMEN, Vol. 55, Issue 2-3, 33-60.

Jensen, T. (2010). "Scientific vs. Religious and Civic Aims of Religion Education: A European Critique of REDCo", Religion \& Education, 37:3, 218-222.

Jensen, T. (2012)."The Muhammad Cartoons; Freedom Fighting and Islam Bashing", In Hafeez, F. (ed.) From the Far Right to the Mainstream. Islamophobia in Perty Politics and the Media, Frankfurt/ New York: Campus Verlag, 91-110.

Jensen, T. (2013). "A Battlefield in the Culture Wars: Religious Education in Danish Elementary School 1989-2011". In Jödicke, A. (ed.) Religious Education Politics, the State, and Society, edited by, Würzburg, ERGON, 25-49.

Jensen, T. (2015). "Religious education (RE) in other kinds of bordertowns: Denmark as an extreme and exemplary case". In: Berglund, J. et al (eds.) Crossings and Crosses. Borders, Educations, and Religions in Northern Europe. Berlin, New York, De Gruyter, 213-238.

Jensen, Tim and Karna Kjeldsen. 2013."RE in Denmark - Political and Professional Discourses and Debates, Past and Present", Temenos, 49:2, 185-223.

Jensen, T. \& K. Kjeldsen (2014a). Baseline Study. European Projects and Recommendations involving Religious Education (RE), EU, Lifelong Learning Programme: Intercultural Education through Religious Studies (IERS). http://iers.unive.it/about/research/ (Last accessed February 22, 2016).

Jensen, T. \& K. Kjeldsen (2014b). Baseline Study. Religious Education in Italy. EU, Lifelong Learning Programme: Intercultural Education through Religious Studies (IERS). http://iers.unive.it/about/ research/ (Last accessed February 22, 2016). 
Jensen, T. \& K. Kjeldsen. (2014c). Baseline Study. Religious Education in Spain. EU, Lifelong Learning Programme: Intercultural Education through Religious Studies (IERS). http://iers.unive.it/about/ research/ (Last accessed February 4, 2015).

Jensen, T. \& K. Kjeldsen. 2014d. Baseline Study. Religious Education in Germany. EU, Lifelong Learning Programme: Intercultural Education through Religious Studies (IERS). http://iers.unive.it/about/ research/ (Last accessed February 22, 2016).

Jensen, T. \& K. Kjeldsen. 2014e. Baseline Study. Religious Education in France. EU, Lifelong Learning Programme: Intercultural Education through Religious Studies (IERS). http://iers.unive.it/about/ research/ (Last accessed February 22, 2016).

Jensen, T. \& K. Kjeldsen. 2014f. Baseline Study. Religious Education in Denmark. EU, Lifelong Learning Programme: Intercultural Education through Religious Studies (IERS). http://iers.unive.it/about/ research/ (Last accessed February 22, 2016).

Jödicke, A. (ed.) (2013). Religious Education Politics, the State, and Society. Würzburg, ERGON.

Kerchove, A. Van den (2011). "Teaching about Religious Issues within the Framework of the French "Laïcité". In Franken, L. \& P. Loobuyck (eds.) Religious Education in a Plural, Secularised Society. A Paradigm Shift, Münster, Waxmann, 55-67.

OSCE/ODIHR (2007). The Toledo Guiding Principles on Teaching about Religions and Beliefs in Public Schools. Retrieved from http:// www.osce.org/odihr/29154

Otterbeck, J. and P. Bevelander (2006). Islamophobi. En studie av begreppet, ungdomars attityder och unga muslimers utsatthet. Stockholm: Forum för levande historia. Retrieved from http:// levandehistoria.se

Religion \& Education. 2010. Volume 37, Number 3. Special Issue on the REDCo project. 
Sakaranaho, T. (2013). "Religious Education in Finland", Temenos, vol. 49, 2, 225-254.

Undervisningsministeriet (2007). Bekendtgørelse om uddannelsen til professionsbachelor som lærer $i$ folkeskolen. BEK nr. 219 af 12.03.2007.

Wiebe, D. (1984). "The Failure of Nerve in the Academic Study of Religion”, Studies of Religion 13, 401-22.

Willaime, J.-P. (2007). "Different models for religion and education in Europe". In Jackson, J. et al (eds.) Religion and education in Europe, Münster, Waxmann, 57-66.

Wolf, V. (2012) Moral - und Werteerziehung im schulischer Kontext. Legitimation und Entwicklung des bekentnissfreien Moralund Werteunterrichts an deutschen Schulen. Masterarbeit, Institut für Theologie und Religionswissenschaft, Leibniz Universität Hannover.

Zuber, V. (2016) "Teaching the Secular Moral Code in French State Schools. The Debate Between Providing an Upbringing and Providing an Education From the French Revolution to Our Time", In Antes, P, Geertz, Ar.W. \& M. Rothstein (eds.) Contemporary Views on Contemporary Religion, in Celebration of Tim Jensen's 65th Birthday, Sheffield/Bristol, Equinox, 283-296. 